\title{
DICIONÁRIO DO INVESTIDOR
}

\author{
JOSÉ RIBAMAR GASPAR FERREIRA \\ Professor da Faculdade de Direito da Universidade \\ Federal do Paraná
}

O estágio de desenvolvimento econômico por que passamos criou atos e instrumentos, ou, pelo menos, pôs em maior atividade tradicionais instrumentos de negociação. E dai, necessariamente, adveio o uso da linguagem própria para esses atos e instrumentos, e, como linguagem, a conveniência de difundi-la.

Nos últimos anos, cobretudo com a dinamização do mercado de capitais e o interesse manifestado por grandes parcelas da população, algumas publicações vieram à luz com glossário de termos do comércio financeiro. Grande parte dessas publicações surgiu por iniciativa de instituições financeiras no trabalho de treinamento e desenvolvimento de seu pessoal. Outra parte apareceu como material de órgãos especializados.

$\mathrm{Na}$ função de assessoria a algumas dessas instituições revimos e coordenamos o que existia publicado. E o resultado foi um pequeno dicionário sobre termos da área financeira.

O Prof. Manoel de Oliveira Sobrinho, Diretor da Faculdade de Direito da Universidade Federal do Paraná viu o dicionário e achou conveniente publicá-lo na Revista da Faculdade como forma de dar, aos jovens estudantes, uma fonte imediata de consulta. Esse gesto é - maior mérito da publịcação que ora se faz como significação do desejo de servir aos educandos. 


\section{INDICE}

A PRAZO $\ldots \ldots \ldots \ldots \ldots \ldots \ldots \ldots$

A VISTA $\ldots \ldots \ldots \ldots \ldots \ldots \ldots \ldots$

ABATIMENTO

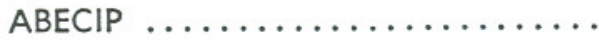

AÇÃO

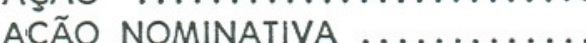

AÇÃO NOMINATIVA ENDOSSÁVEL

AÇÃO ORDINÁRIA ...........

AÇÃO AO PORTADOR ...........

AÇÃO PREFERENCIAL $\ldots \ldots \ldots \ldots$.

ACEITE $\ldots \ldots \ldots \ldots \ldots \ldots \ldots \ldots$

ACCEPTANCE (FUNDO DE) .......

ACIONISTA $\ldots \ldots \ldots \ldots \ldots \ldots \ldots$

ACREFI $\ldots \ldots \ldots \ldots \ldots \ldots \ldots \ldots$

ACUMULAÇÃO $\ldots \ldots \ldots \ldots \ldots \ldots$

ADITIVO

ADMINISTRAÇÃO DE CARTEIRAS ...

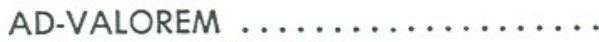

AGENTE AUTÔNOMO ..........

AGENTE FINANCEIRO $\ldots \ldots \ldots \ldots$

ÁGIO $\ldots \ldots \ldots \ldots \ldots \ldots \ldots \ldots$

ALIENAÇÃO FIDUCIÁRIA EM GA-

RANTIA

ALONGO $\ldots \ldots \ldots \ldots \ldots \ldots \ldots$

ALTA

ALVARÁ

AMORTIZAÇÃO $\ldots \ldots \ldots \ldots \ldots \ldots$

ANÁLISE DE BALANÇO .........

ANÁLISE DE MERCADO .........

ANBID $\ldots \ldots \ldots \ldots \ldots \ldots \ldots \ldots$

APE

APLICAÇÃO $\quad \ldots \ldots \ldots \ldots \ldots \ldots \ldots$

APÓLICE REAJUSTÁVEL DO TESOURO

MUNICIPAL

ARBITRAGEM .............

ATIVO $\ldots \ldots \ldots \ldots \ldots \ldots \ldots \ldots$

AVAL $\ldots \ldots \ldots \ldots \ldots \ldots \ldots \ldots \ldots \ldots$

AVERBAÇÃO $\ldots \ldots \ldots \ldots \ldots \ldots$

BAIXA $\ldots \ldots \ldots \ldots \ldots \ldots \ldots$

BALANÇO $\ldots \ldots \ldots \ldots \ldots \ldots \ldots$

BANCO CENTRAL DO BRASIL ......

BANCO DO BRASIL ...........

BANCO COMERCIAL ............

BANCO DE DESENVOLVIMENTO ....

BANCO DE INVESTIMENTO
15

15

15

15

15

15

15

16

16

16

17

17

17

17

17

17

17

17

18

18

18

18

18

18

18

18

19

19

19

19

19

20

20

20

20

20

20
BLOCK TRADE $\ldots \ldots \ldots \ldots \ldots \ldots \ldots \quad 22$

BLUE CHIP ............... 22

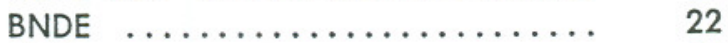

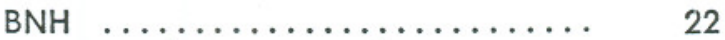

BOLETIM (DAS BOLSAS) ........ 22

BOLETO (BOLETA) ........... 23

BOLSA ................ 23

BOLSA DE VALORES .......... 23

BONECO $\ldots \ldots \ldots \ldots \ldots \ldots \ldots \ldots \ldots .23$

BONIFICAÇÃO $\ldots \ldots \ldots \ldots \ldots \ldots . \ldots \ldots$

BONUS $\ldots \ldots \ldots \ldots \ldots \ldots \ldots \ldots \ldots$

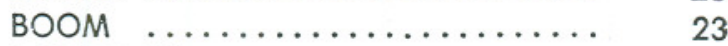

BORDERAU $\ldots \ldots \ldots \ldots \ldots \ldots \ldots .24$

CADERNETA DE POUPANÇA ...... 24

CAIXAS DE LIQUIDAÇÃO ......... 24

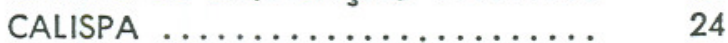

CÂMARA DE COMPENSAÇÃO ..... 24

CAMBIAL ............... 24

CÂMBIO $\ldots \ldots \ldots \ldots \ldots \ldots \ldots \ldots \ldots . \ldots \ldots$

CÂMBIO LIVRE $\ldots \ldots \ldots \ldots \ldots \ldots \ldots \ldots$.

CÂMBIO MANUAL ............ 25

CÂMBIO OFICIAL ............. 25

CÂMBIO PARALELO (negro) ....... 25

CAPATAZIA $\ldots \ldots \ldots \ldots \ldots \ldots \ldots .25$

CAPITAL $\ldots \ldots \ldots \ldots \ldots \ldots \ldots \ldots$.

CAPITAL $\ldots \ldots \ldots \ldots \ldots \ldots \ldots \ldots .25$

CAPITAL ABERTO (Sociedade de) ... 25

CAPITAL CIRCULANTE .......... 25

CAPITAL FECHADO (Sociedade de) .. $\quad 25$

CAPITAL FIXO ............... 25

CAPITAL DE GIRO ............ 25

CARÊNCIA $\ldots \ldots \ldots \ldots \ldots \ldots \ldots 26$

CARTEIRA $\ldots \ldots \ldots \ldots \ldots \ldots \ldots \ldots .26$

CARTEIRA DE CRÉDITO ......... 26

CARTEIRA DE TÍTULOS .......... 26

CARTEL $\ldots \ldots \ldots \ldots \ldots \ldots \ldots \ldots \ldots . \ldots \ldots$

CAUÇÃO $\ldots \ldots \ldots \ldots \ldots \ldots \ldots . \ldots \ldots$

CAUTELA $\ldots \ldots \ldots \ldots \ldots \ldots \ldots \ldots 26$

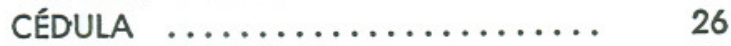

CÉDULA HIPOTECÁRIA $\ldots \ldots \ldots \ldots .26$

CÉDULA PIGNORATÍCIA $\ldots \ldots \ldots \ldots .27$

CERTIFICADO $\ldots \ldots \ldots \ldots \ldots \ldots \ldots .27$

CHEQUE $\ldots \ldots \ldots \ldots \ldots \ldots \ldots \ldots \ldots$

CLUBE DE INVESTIMENTOS ....... 28

CNBV ................. 28 


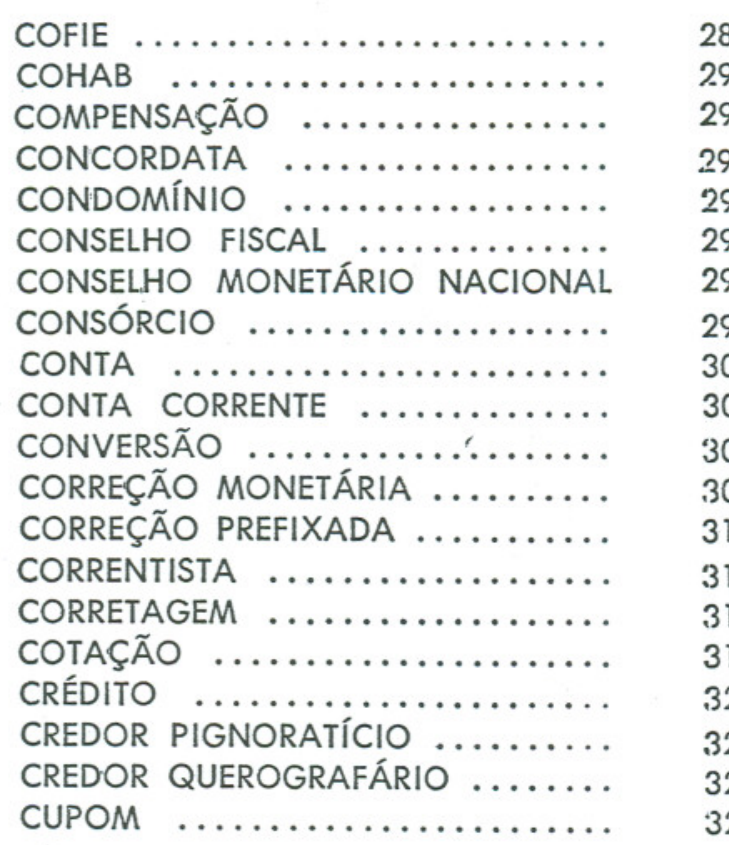

DEALER $\ldots \ldots \ldots \ldots \ldots \ldots \ldots \ldots . \ldots \ldots$

DEBÊNTURE $\ldots \ldots \ldots \ldots \ldots \ldots \ldots \ldots \ldots \ldots$

DECRETO-LEI $157 \ldots \ldots \ldots \ldots \ldots \ldots$.

DEFICIT $\ldots \ldots \ldots \ldots \ldots \ldots \ldots \ldots .33$

DEL-CREDERE $\ldots \ldots \ldots \ldots \ldots \ldots \ldots$

DELIBERAÇÃO $\ldots \ldots \ldots \ldots \ldots \ldots \ldots \ldots . .33$

DEPÓSITOS $\ldots \ldots \ldots \ldots \ldots \ldots \ldots \ldots \ldots \ldots . .33$

DEPÓSITO MERCANTIL ........... 34

DESÁGIO ................... 34

DESDOBRAMENTO ............. 34

DINHEIRO À VISTA ............ 35

DINHEIRO EM ESPÉCIE ......... 35

DINHEIRO A RISCO ............ 35

DIREITOS ................... 35

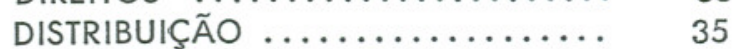

DIVIDENDO $\ldots \ldots \ldots \ldots \ldots \ldots \ldots \ldots . .36$

DOMÍNIO $\ldots \ldots \ldots \ldots \ldots \ldots \ldots \ldots \ldots \ldots . .36$

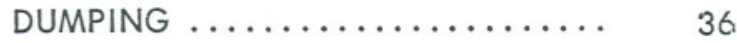

DUPLICATA $\ldots \ldots \ldots \ldots \ldots \ldots \ldots \ldots \ldots \ldots$

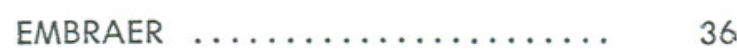

EMBRATUR $\ldots \ldots \ldots \ldots \ldots \ldots \ldots \ldots \ldots \ldots \ldots \ldots$

EMITENTE $\ldots \ldots \ldots \ldots \ldots \ldots \ldots \ldots \ldots \ldots \ldots \ldots$

EMPENHAR $\ldots \ldots \ldots \ldots \ldots \ldots \ldots \ldots \ldots$

EMPRESAS COLIGADAS ...........

EMPRESA SUBSIDIÁRIA (Vinculada ou controlada) ....................

EMPRÉSTIMO $\ldots \ldots \ldots \ldots \ldots \ldots$

ENDOSSO $\ldots \ldots \ldots \ldots \ldots \ldots \ldots$

ESPECULAR $\ldots \ldots \ldots \ldots \ldots \ldots \ldots$

EXTRATO DE CONTA ..............

FALÊNCIA $\ldots \ldots \ldots \ldots \ldots \ldots \ldots$ FATURA FISCAL (ou Nota Fiscal) ... FATURA SIMPLES (ou Conta de Ven-

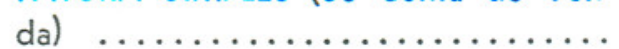
FAVORECIDO

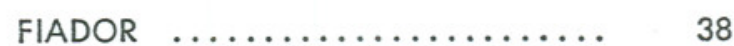

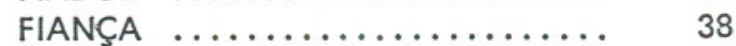

FIDUCIAL $\ldots \ldots \ldots \ldots \ldots \ldots \ldots \ldots \ldots \ldots \ldots \ldots$

FILHOTE $\ldots \ldots \ldots \ldots \ldots \ldots \ldots \ldots \ldots \ldots \ldots \ldots, \quad 38$

FINAME $\ldots \ldots \ldots \ldots \ldots \ldots \ldots \ldots \ldots \ldots \ldots \ldots$

FINANCEIRAS $\ldots \ldots \ldots \ldots \ldots \ldots \ldots . \ldots \ldots$

FINANCIAMENTO $\ldots \ldots \ldots \ldots \ldots \ldots . . \ldots . \ldots$

FUNDAMENTALISTA $\ldots \ldots \ldots \ldots \ldots$.

FUNDO .................... 39

FUNDOS DE INCENTIVOS FISCAIS . 39

FUNDO MÚTUO DE INVESTIMENTOS 39

FUNDO DE RESERVA LEGAL ....... 40

FUSÃO DE EMPRESAS $\ldots \ldots \ldots \ldots .40$

GARANTIA $\ldots \ldots \ldots \ldots \ldots \ldots \ldots . . \ldots \%$

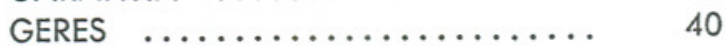

GRÁFICO PONTO-FIGURA ......... 40

GRAFISTA $\ldots \ldots \ldots \ldots \ldots \ldots \ldots . \quad 40$

HIPOTECA $\ldots \ldots \ldots \ldots \ldots \ldots \ldots ., 40$

HOLDING $\ldots \ldots \ldots \ldots \ldots \ldots \ldots . . . \ldots$

IBDF $\ldots \ldots \ldots \ldots \ldots \ldots \ldots \ldots, 41$

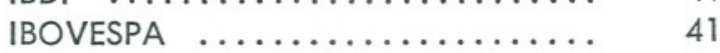

IMPOSTO DE RENDA ............. 41

IMPOSTO RETIDO NA FONTE ..... 41

INBV $\ldots \ldots \ldots \ldots \ldots \ldots \ldots \ldots \ldots \ldots, 41$

INCENTIVOS FISCAIS .......... 41

NCORPORAÇÃO DE EMPRESAS .... 41

INCORPORAÇÃO DE RESERVAS ... 42

INCORPORADOR $\ldots \ldots \ldots \ldots \ldots \ldots, 42$

INDENIZAÇÃO $\ldots \ldots \ldots \ldots \ldots \ldots \ldots .42$

ÍNDICE $\ldots \ldots \ldots \ldots \ldots \ldots \ldots \ldots, 42$

INFLAÇÃO $\ldots \ldots \ldots \ldots \ldots \ldots \ldots . .42$

INSOLVÊNCIA ................. 42

INTEGRALIZAÇÃO $\ldots \ldots \ldots \ldots \ldots . .42$

INVENTÁRIO $\ldots \ldots \ldots \ldots \ldots \ldots \ldots . .42$

INVESTIDOR $\ldots \ldots \ldots \ldots \ldots \ldots \ldots \ldots, 42$

INVESTMENTO $\ldots \ldots \ldots \ldots \ldots \ldots \ldots, 43$

ISENÇÃO FISCAL $\ldots \ldots \ldots \ldots \ldots \ldots, 43$

JURO $\ldots \ldots \ldots \ldots \ldots \ldots \ldots \ldots, 43$

JUROS DE MORA $\ldots \ldots \ldots \ldots \ldots \ldots$

LANÇAMENTO $\ldots \ldots \ldots \ldots \ldots \ldots . .43$

LANCE $\ldots \ldots \ldots \ldots \ldots \ldots \ldots \ldots . \ldots \ldots$

LEASING $\ldots \ldots \ldots \ldots \ldots \ldots \ldots \ldots \ldots \ldots$

LETRA BANCÁRIA .............. 43

LETRA DE CÂMARA ............. 43

LETRA DE CÂMBIO .............. 44

LETRA HIPOTECÁRIA ............ 44

LETRA IMOBILIÁRIA ............. 44

LETRA À PRÊMIO ............... 44

LETRA DO TESOURO NACIONAL ... 44

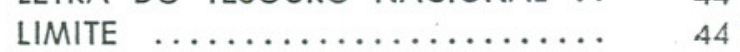

38 LIQUIDAÇÃO $\ldots \ldots \ldots \ldots \ldots \ldots \ldots \ldots \ldots$

LIQUIDEZ $\ldots \ldots \ldots \ldots \ldots \ldots \ldots \ldots \ldots \ldots \ldots \ldots \ldots \ldots$

38 LIQUIDEZ BANCÁRIA $\ldots \ldots \ldots \ldots .45$

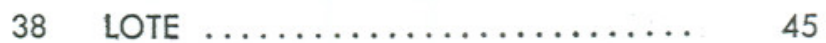


MARGEM

MERCADO $\ldots \ldots \ldots \ldots \ldots \ldots \ldots$

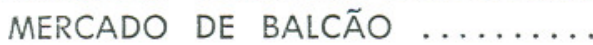

MERCADO DE CAPITAIS ..........

MERCADO ESTREITO ............

MERCADO FINANCEIRO $\ldots \ldots \ldots \ldots$

MERCADO FIRME $\ldots \ldots \ldots \ldots \ldots$

MERCADO FRACIONÁRIO .......

MERCADO IMOBILIÁRIO $\ldots \ldots \ldots \ldots$

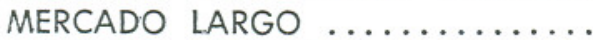

MERCADO MOBILIÁRIO ..........

MERCADO NACIONAL $\ldots \ldots \ldots \ldots$

MERCADO PARALELO $\ldots \ldots \ldots \ldots \ldots$

MERCADO PRIMÁRIO ...........

MERCADO SECUNDÁRIO .........

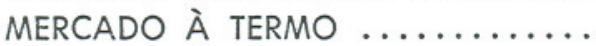

MERCADO À VISTA ............

MOEDA CORRENTE $\ldots \ldots \ldots \ldots \ldots$

MOEDA FIDUCIÁRIA ...........

MONOPÓLIO $\ldots \ldots \ldots \ldots \ldots \ldots \ldots$

MORA $\ldots \ldots \ldots \ldots \ldots \ldots \ldots$.

MORATÓRIA $\ldots \ldots \ldots \ldots \ldots \ldots$

MUTUANTE $\ldots \ldots \ldots \ldots \ldots \ldots$

MUTUÁRIO $\ldots \ldots \ldots \ldots \ldots \ldots \ldots$

NEGÓCIO DIRETO $\ldots \ldots \ldots \ldots \ldots \ldots$

NOTA PROMISSÓRIA $\ldots . . . \ldots \ldots$

NOTA PROMISSÓRIA RURAL ......

NOVAÇÃO $\ldots \ldots \ldots \ldots \ldots \ldots$

NUMERÁRIO EFETIVO ...........

OBRIGAÇÕES REAJUSTÁVEIS DO TE-

SOURO NACIONAL

OPEN MARKET

OPERAÇÃO A TERMO $\cdots \cdots \cdots \cdots$

OPERAÇÃO À VISTA $\ldots \ldots \ldots \ldots \ldots$

OPERADOR $\ldots \ldots \ldots \ldots \ldots \ldots \ldots$

ORÇAMENTO $\ldots \ldots \ldots \ldots \ldots \ldots \ldots$

ORÇAMENTO PÚBLICO $\ldots \ldots \ldots \ldots$

ORDEM FIRME $\ldots \ldots \ldots \ldots \ldots \ldots$

ORDEM DE OPERAÇÕES $\ldots \ldots \ldots \ldots$

ORDEM DE PAGAMENTO ........

OSCILAÇÃO DE TÍTULOS

PATRIMÔNIO LÍQUIDO

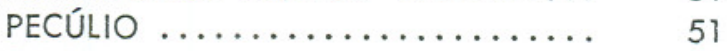

PENHOR $\ldots \ldots \ldots \ldots \ldots \ldots \ldots \ldots \ldots \ldots \ldots \ldots \ldots \ldots$

PESSOA FÍSICA ............ 51

PESSOA JURÍDICA $\ldots \ldots \ldots \ldots \ldots \ldots \quad 51$

PONTE $\ldots \ldots \ldots \ldots \ldots \ldots \ldots \ldots \ldots$

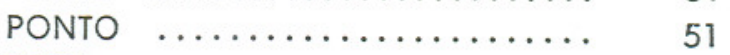

POOL $\ldots \ldots \ldots \ldots \ldots \ldots \ldots \ldots \ldots \ldots$

POTFOLIO ................ 51

POSTO ................ 51

POUPANÇA $\ldots \ldots \ldots \ldots \ldots \ldots \ldots$

PRAZO $\ldots \ldots \ldots \ldots \ldots \ldots \ldots \ldots \ldots \ldots \quad 52$

PRAZO FIXO $\ldots \ldots \ldots \ldots \ldots \ldots \ldots \ldots \quad 52$

PRAZO DE SUBSCRIÇÃO ......... 52

PREÇO/LUCRO $\ldots \ldots \ldots \ldots \ldots \ldots \ldots . \ldots \ldots$

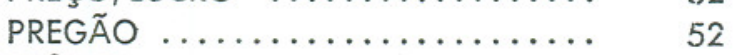

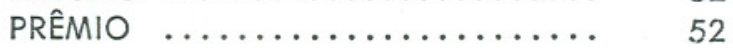

PRO-LABORE $\ldots \ldots \ldots \ldots \ldots \ldots \ldots \ldots \quad 52$

PRO RATA TEMPORIS ........ 53

QUITAÇÃO (ou Recibo) ......... 53

QUOTA $\ldots \ldots \ldots \ldots \ldots \ldots \ldots \ldots . \ldots \ldots$

QUORUM ................ 53

RATIO $\ldots \ldots \ldots \ldots \ldots \ldots \ldots \ldots \ldots$

REAPLICAÇÃO $\ldots \ldots \ldots \ldots \ldots \ldots \ldots$

RECEITA $\ldots \ldots \ldots \ldots \ldots \ldots \ldots \ldots \ldots$

RECIBO DE TÍTULO ............ 54

REDESCONTO $\ldots \ldots \ldots \ldots \ldots \ldots \ldots \ldots . \ldots \ldots$

RÉDITO $\ldots \ldots \ldots \ldots \ldots \ldots \ldots \ldots \ldots . \quad 54$

REEMBOLSA $\ldots \ldots \ldots \ldots \ldots \ldots \ldots .54$

REFORMA (de título) .......... 54

RENDA FIXA .............. 54

RENDA VARIÁVEL ........... 54

RENDIMENTO ............. 54

RENTABILIDADE $\ldots \ldots \ldots \ldots \ldots \ldots \ldots \quad 54$

RESERVAS $\ldots \ldots \ldots \ldots \ldots \ldots \ldots \ldots .54$

RESERVA DE DOMÍNIO ........ 55

RESGATE $\ldots \ldots \ldots \ldots \ldots \ldots \ldots \ldots \ldots$

SACADO $\ldots \ldots \ldots \ldots \ldots \ldots \ldots \ldots . \ldots \ldots$

SACADOR $\ldots \ldots \ldots \ldots \ldots \ldots \ldots \ldots$

SALDO MÉDIO ............. 55

SEGURANÇA $\ldots \ldots \ldots \ldots \ldots \ldots \ldots . \quad 55$

SEGURIO $\ldots \ldots \ldots \ldots \ldots \ldots \ldots \ldots \ldots . \quad 55$

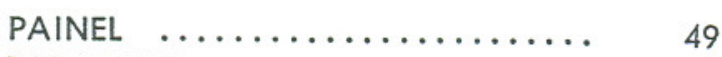

PAPAGAIO $\ldots \ldots \ldots \ldots \ldots \ldots \ldots . . \ldots$

PAPEL $\ldots \ldots \ldots \ldots \ldots \ldots \ldots \ldots \ldots$

PAPEL COMERCIAL $\ldots \ldots \ldots \ldots \ldots . \quad 50$

SOCIEDADE ANÔNIMA ......... 55

SOCIEDADE DE CAPITAL AUTORIZA-

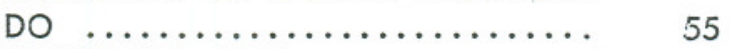

SOCIEDADE CIVIL .......... 56

SOCIEDADE CORRETORA ........ $\quad 56$

PAPEL FRIO $\ldots \ldots \ldots \ldots \ldots \ldots \ldots \ldots .50$

PAPEL QUENTE $\ldots \ldots \ldots \ldots \ldots \ldots \ldots, \quad 50$

SOCIEDADE DE CRÉDITO, FINANCIA-

RIO $\ldots \ldots \ldots \ldots \ldots \ldots \ldots \ldots \ldots \ldots$

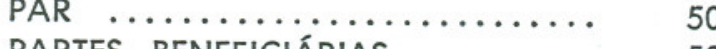

SOCIEDADE DE CRÉDITO, FINANCIA-

PARTES DE FUNDADOR $\ldots \ldots \ldots \ldots$.

MENTO E INVESTIMENTOS ....... 56

PARTICIPAÇÃO ............. 50

SOCIEDADE DISTRIBUIDORA ...... 56

SOCIEDADE LIMITADA ......... 56

PASSIVO $\ldots \ldots \ldots \ldots \ldots \ldots \ldots \ldots \ldots \ldots \ldots \ldots$

SUBSCRIÇÃO $\ldots \ldots \ldots \ldots \ldots \ldots \ldots .56$

PATRIMÔNIO $\ldots \ldots \ldots \ldots \ldots \ldots \ldots . . \ldots 1$

SUCURSAL

56 


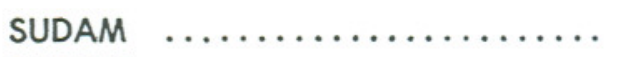

SUDENE $\ldots \ldots \ldots \ldots \ldots \ldots \ldots \ldots$

SUDEPE $\ldots \ldots \ldots \ldots \ldots \ldots \ldots \ldots \ldots$

SUPERAVIT

SWAP

TARIFA

TAXA

TAXAS DE BOLSA

TENDÊNCIA

TERMO

TIED LOAN

TÍTULO DE CRÉDITO

TÍTULO DE DÍVIDA PÚBLICA

TÍTULO DE FAVOR

TÍTULO AO PORTADOR

TOMADOR
57 TRUST COMPANY ........... 59

57

57 UNDERWRITING ............. 59

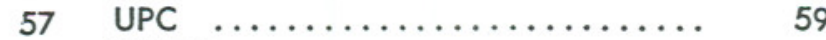

57 USURA $\ldots \ldots \ldots \ldots \ldots \ldots \ldots \ldots \ldots \ldots \ldots \ldots \ldots$

57 VALE $\ldots \ldots \ldots \ldots \ldots \ldots \ldots \ldots \ldots$

57 VALOR NOMINAL ............ 60

57 VALOR REAL $\ldots \ldots \ldots \ldots \ldots \ldots \ldots .6 \ldots \ldots \ldots \ldots \ldots \ldots$

58 VALOR DE RESGATE ........... 60

58 VALOR VENAL ............... 60

58 VALORES MOBILIÁRIOS ......... 60

58 VALORIZAÇÃD $\ldots \ldots \ldots \ldots \ldots \ldots \ldots 60$

58 VENCIMENTO ............... 60

59 VOTO (Direito de) .............. 61

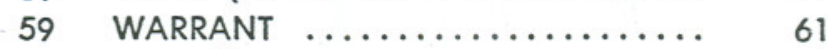

59 ZANGÃO $\ldots \ldots \ldots \ldots \ldots \ldots \ldots \ldots$ 


\section{A PRAZO}

diz-se do pagamento, de uma só vez ou em parcelas, que deva ser realizado posteriormente à concretização do negócio. O prazo pode ser curto, médio ou longo; ser parcelado, ou devido de uma só vez.

\section{À VISTA}

diz-se do pagamento ou recebimento feito contra entrega do bem ou do valor adquirido.

\section{ABATIMENTO}

ação ou efeito de abater; desconto, redução no preço; redução no imposto de renda a pagar, pelas pessoas físicas, especialmente quando se fazem determinados investimentos de capital.

\section{ABECIP}

Associação Brasileira das Entidades de Poupança e Empréstimo: entidade que congrega instituições financeiras filiadas ao Sistema Brailleiro de Poupança e Empréstimo, vinculado ao $\mathrm{BNH}$.

AÇÃo

título de propriedade, transferível, que representa a menor fração indivisível do capital das sociedades anônimas.

\section{AÇÃO NOMINATIVA}

ação que identifica seu possuidor. A propriedade deve ser registrada em livro especial, onde também constarão eventuais transferências de propriedade.

\section{AÇÃO NOMINATIVA ENDOSSÁVEL}

tem a mesma caracterização da ação nominativa; sua transferência, porém, opera-se pelo endosso em preto no cer- 
tificado correspondente; a transferência em livro próprio é realizada a posteriori.

\section{AÇÃO ORDINÁRIA}

título de propriedade que confere ao titular o direito de voto, bem como a participação integral nos resultados da empresa.

\section{AÇÃO AO PORTADOR}

título de propriedade que confere os direitos acionários a seu portador; pertence a quem a detiver em seu poder, e tal poder é transferido mediante simples entrega do certificado correspondente.

\section{AÇÃO PREFERENCIAL.}

título de propriedade que dá ao titular prioridade no recebimento de dividendos e no reembolso do capital; ou ambas as coisas. Normalmente, a ação preferencial não confere poder de voto ao titular, ainda que possa fazê-lo. A ação preferencial pode adquirir poder de voto, desde que determinadas condições estatutárias não sejam obedecidas.

\section{SIGLAS REPRESENTATIVAS}

$\mathrm{OP}=$ ação ordinária ao portador;

ON = ação ordinária nominativa;

$\mathrm{PP}=$ ação preferencial ao portador;

$\mathrm{PN}=$ ação preferencial nominativa;

$\mathrm{CB}=$ usada nos Boletins de Bolsa para indicar que determinada ação está sendo negociada "com bonificação" (com direito a bonificação). Sem esse direito, a ação é negociada EB (ex-bonificação).

$C D=$ usada nos Boletins de Bolsa para indicar que a ação está sendo negociada "com direitos" ou "com dividendos". Depois de exercido o direito, ou recebidos os dividendos, a ação passa a ser negociada ED (ex-direitos ou ex-dividendos).

CS = usada nos Boletins de Bolsa para indicar que a ação está sendo negociada com direito a subscrever novas ações, subscrição essa já vo- 
tada pela Assembléia de Acionistas da empresa, e em fase de execução.

As ações que já exerceram esse direito serão apregoadas em Bolsa com ES (ex-subscrição), também apelidadas "ações limpas".

\section{ACEITE}

declaração, numa duplicata ou letra de câmbio, pela qual o sacado ou terceiros se comprometem a quitar o débito representado pelo título, na data aprazada e na praça indicada no título.

\section{ACCEPTANCE (FUNDO DE)}

acumulação de recursos de diversos investidores, para aplicação em títulos de crédito.

\section{ACIONISTA}

titular de ações de uma sociedade anônima.

\section{ACREFI}

Associação das Empresas de Crédito, Financiamento e Investimento de São Paulo; congrega as instituições financeiras do setor de financiamento; em outros estados ADECIF (GB), AMECIF (MG), AGECIF (RS), ADECRENE (PE e outros estados do Nordeste).

\section{ACUMULAÇÃO}

fase do mercado de ações em que poucos investidores acumulam estoques elevados de ações, para depois distribuí-las entre a grande massa de investidores.

\section{ADITIVO}

condições suplementares inseridas num contrato.

\section{ADMINISTRAÇÃO DE CARTEIRAS}

ato de gerir, manter sob guarda, carteiras de títulos pertencentes a terceiros, movimentando-as por conta e ordem do titular, e prestando contas periodicamente da situação da carteira a seu possuidor.

\section{AD-VALOREM}

direitos alfandegários cobrados sobre o valor da fatura consular de mercadorias. 


\section{AGENTE AUTONNOMO}

pessoa dedicada à venda de títulos e valores mobiliários, além de outros serviços financeiros, junto ao público. Só pode operar desde que credenciado pelo Banco Central do Brasil, e vinculando-se a uma instituição financeira.

\section{AGENTE FINANCEIRO}

intermediário de assuntos financeiros. Instituição Financeira que aproxima o investimento do crédito a conceder. Coobrigado em operações de financiamento com fundos oficiais, ou repasses de agências de fomento e desenvolvimento, nacionais e internacionais.

ÁGIO

importância adicionada ao valor nominal de um título, quando de uma transação (venda ou subscrição). Normalmente usado só no último caso (subscrição). A importância cobrada como ágio nas subscrições de ações pode ser incorporada às reservas da sociedade anônima, ou reverter em benefício dos acionistas lançadores da subscrição, quando estes abrem mão de seus direitos de subscrição.

\section{ALIENAÇÃO FIDUCIÁRIA EM GARANTIA}

garantia de dívida, pela qual o credor - instituição financeira - adquire a propriedade resolúvel e a posse indireta, de um móvel, que fica na posse direta do devedor. Sendo obrigação do devedor o pagamento do bem financiado, a garantia subsiste até a quitação total da dívida.

\section{ALONGO}

retângulo de papel, de mesmas dimensões que as da cambial, a ela colado, quando seu verso se encontra inteiramente tomado pelos endossos.

ALTA

tendência do mercado em que, por causa de uma pressão de compra, o preço de um ou de vários papéis sofre elevação.

ALVARÁ

forma especial de provisão, em que o juiz aprova ou cer tifica alguma medida, ou confirma algum estado ou direito. Documento passado pelo juiz, ordenando ou reconhecendo atos e direitos. Despacho, licença, ordem da autoridade constituída. 


\section{VENDA POR ALVARÁ}

a venda que se realiza de bens de pessoas que, por outra forma, estariam interditas para concretizá-la.

\section{AMORTIZAÇÃO}

ato de pagar parte de um débito contraído em terceiros.

\section{ANÁLISE DE BALANÇO}

decomposição de um balanço, para efeito de exame, observação e crítica. O estudo do comportamento financeiro da empresa, com base nos seus demonstrativos financeiros.

\section{BALANÇO HORIZONTAL}

evolução das contas de mais de um balanço, para observação do comportamento comparado daquela conta, no transcorrer de mais de um exercício.

\section{BALANÇO VERTICAL}

decomposição percentual de um grupo de contas, para observar a incidência de cada uma no agrupamento.

\section{ANALISTA DE BALANÇO}

o técnico que procede à análise de balanço.

\section{ANÁLISE DE MERCADO}

exame, observação e crítica do comportamento e tendências de um mercado determinado, realizada em função de índices das cotações de ações e do volume de negócios ocorrido num espaço de tempo específico. O resultado desse exame.

\section{ANALISTA DO MERCADO}

- técnico que procede à análise do mercado, e o acompanha visando ao exame e à crítica.

\section{ANBID}

Associação Nacional dos Bancos de Investimento e Desenvolvimento; entidade que congrega essas instituições financeiras, com sede no Rio de Janeiro.

\section{APE}

Associação de Poupança e Empréstimo - sociedade que aplica as contribuições de associados na concessão de em- 
préstimos, aos próprios cooperados, com determinadas finalidades. Especificamente, entidades que atuam desta forma, e pertencentes ao Sistema Brasileiro de Poupança e Empréstimo, filiadas ao Sistema Financeiro da Habitação.

\section{APLICAÇÃO}

ato de aplicar; investir dinheiro na compra de títulos, ou valores mobiliários, com a finalidade de auferir rendimento.

\section{APÓLICE}

papel que representa uma obrigação de pagar, da dívida pública, comercial ou civil. Usa-se também para designar o contrato de seguro.

\section{APÓlice REAJUSTÁVEL DO TESOURO MUNICIPAL}

título da dívida pública, emitido pela Prefeitura do Município de São Paulo, vencendo juros e correção monetária. Os prazos variam até 3 anos, e a taxa de juros é crescente de acordo com o prazo de resgate. No mercado secundário, as Apólices Reajustáveis são cotadas na Bolsa de Valores de São Paulo.

\section{ARBITRAGEM}

Compra e venda simultânea de um mesmo papel, em praças diferentes, com o objetivo de se beneficiar de uma discrepância de preços entre as praças.

\section{ATIVO}

totalidade de bens e valores de uma empresa ou pessoa inclusive seus direitos, mesmo que dependentes de avaliação.

AVAL

garantia de pagamento dada por terceiros, estranhos a uma dívida, mediante assinatura aposta no título cambial ou documento comprobatório dessa dívida.

\section{AVERBAÇÃO}

confirmação do recolhimento de tributo, dada pelo órgão fiscal; registro da transferência de título de propriedade, ou de vínculo estabelecido sobre determinado título ou valor. 


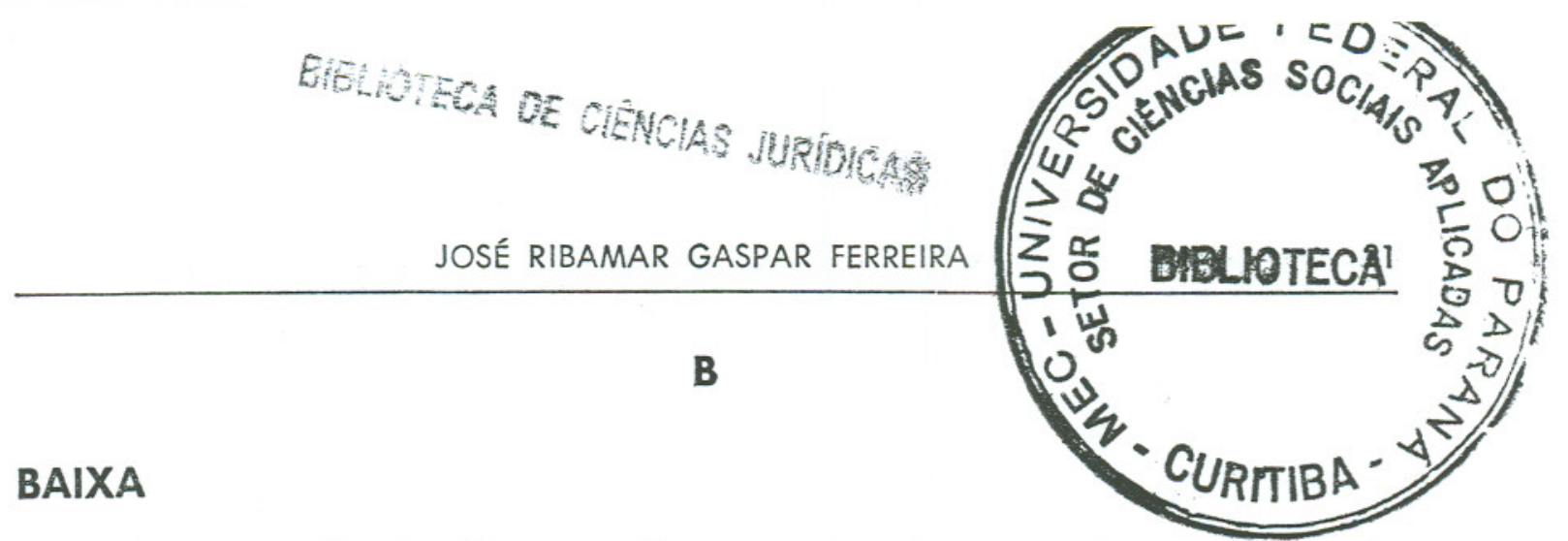

tendência do mercado em que, por causa de uma pressão de venda, o preço de um ou de vários papéis sofre redução nas cotações.

\section{BALANÇO}

demonstração contábil e financeira, levantada ao fim de cada exercício ou periodicamente, para tornar público o estado patrimonial e a situação econômico-financeira de uma empresa.

\section{BANCO CENTRAL DO BRASIL}

órgão federal executor e normativo; agente fiscalizador das normas baixadas pelo Conselho Monetário Nacional. Entre suas diretorias, existe a do Mercado de Capitais, encarregada de dar curso às normas estabelecidas para o perfeito funcionamento dos mercados de títulos e valores mobiliários.

\section{BANCO DO BRASIL}

agente financeiro do Governo federal, atua como banco comercial e como instituição financeira de fomento às atividades básicas do País. Suas ações são "blue-chips", nas Bolsas de Valores.

\section{BANCO COMERCIAL}

instituição financeira dedicada às operações de desconto, depósitos, empréstimos de curto prazo, saques, cobranças, câmbio e outros serviços (transferências, acolhimento de tributos e taxas, etc.).

\section{BANCO DE DESENVOLVIMENTO}

também conhecido como banco de fomento; instituição financeira que destina recursos para amparar financeiramente, atividades industriais, comerciais ou agrícolas oferecendo crédito dirigido à atividade econômica.

\section{BANCO DE INVESTIMENTO}

instituição financeira que opera especialmente na captação e aplicação de recursos a longo prazo. Entre as aplicações mais comuns: repasses de recursos do exterior, financia- 
mento ao capital de giro das empresas, emissão de certificados de depósito bancário com correção monetária, operações de lançamento de novos títulos ("underwriting"), lançamentos secundários de ações, administração de fundos - mútuos e fiscais - e de carteiras individuais de títulos e valores.

\section{BLOCK TRADE}

também chamado "big block trade"; expressão americana que designa a transação de lotes desproporcionalmente grande de ações, de uma só vez.

\section{BLUE CHIP}

ação de grande procura, por suas características de segurança, rentabilidade e liquidez; as ações mais solicitadas do mercado acionário.

BNDE

empresa pública que canaliza e orienta recursos de investimentos para o desenvolvimento econômico do País, operando diretamente ou garantindo transações aprovadas oficialmente, e concedendo créditos a longo prazo para empreendimentos enquadrados, em seus programas de fomento à atividade econômica.

\section{BNH ((Banco Nacional de Habiłação)}

instituição financeira vinculada ao Ministério do Interior, destinada a angariar, canalizar e controlar os recursos para - Plano Nacional da Habitação. O BNH capta recursos do público e de agências de fomento, financia a casa própria, programas de saneamento urbano e a indústria de construção civil.

\section{BOLETIM (DAS BOLSAS))}

Resumo diário do movimento das Bolsas. Neste boletim constam o comportamento do índice (indicando abertura, fechamento, médio, evolução), quantidade de negócios realizados, quantidade de títulos transacionados, volume em cruzeiros, ações que mais subiram, ações que mais baixaram, ações mais negociadas em cruzeiros, cotações de abertura, fechamento, preço máximo, preço mínimo, etc. Algumas Bolsas inserem nesse boletim informações sobre assembléias de empresas, assim como análise do comportamento de suas ações. 


\section{BOLETO (BOLETA)}

documento simplificado, utilizado nos pregões de Bolsa de Valores, onde as partes (comprador e vendedor) contratam, por escrito, o lote transacionado e as condições do negócio. O boleto discrimina quem comprou, quem vendeu, o que se negociou, a que preço, em que condições, qual o valor do lote, e em que data.

BOLSA

genericamente, o recinto onde se negociam valores e mercadorias; aproximando a oferta da procura e criando preços certos e ajustados entre as partes, as Bolsas tornam público o negócio, facilitando-o e assegurando a fixação de preços correntes para os bens negociados.

\section{BOLSA DE VALORES}

instituição financeira na qual se reunem os representantes das Sociedades Corretoras para realizarem, em nome próprio ou de terceiros, negócios com títulos e valores mobiliários. Por delegação oficial, exercem ainda ação fiscalizadora sobre o mercado de ações.

BONECO

diferença irregular de preço, em uma operação, em benefício de corretor inescrupuloso.

\section{BONIFICAÇÃO}

filhote; ação distribuída gratuitamente aos acionistas, como consequência de aumentos de capital por incorporação de reservas e lucros ainda não distribuídos, ou por reavaliação do ativo imobilizado.

\section{BONUS}

título da dívida pública; bonus rotativos; títulos estaduais, emitidos em São Paulo, pela Secretaria da Fazenda estadual, garantido pelo governo do Estado e destinado à financiamento de obras e antecipação de receita tributária.

\section{BOOM}

fase do mercado de ações, caracterizada por aumento inopinado do volume de transações, como pressão de compra e normalmente, elevação das cotações dos títulos. 
BORDERAU

relação dos títulos de crédito que um cliente leva a um Banco para realizar operação de desconto, cobrança, caução, etc.

\section{C}

\section{CADERNETA DE POUPANÇA}

livro onde se lançam os depósitos de poupança livre instituídos pelas entidades do Sistema Brasileiro de Poupança e Empréstimo, vinculado ao $\mathrm{BNH}$.

\section{CAIXAS DE LIQUIDAÇÃO}

entidades ligadas às Bolsas de Valores, encarregadas de promover o registro de liquidação e a compensação de operações à vista e a termo, realizados em Bolsa de responsabilidade de Sociedades Corretoras associadas ou de seus comitentes. Executam ainda emissão de certificados, negociáveis ou não, visando o resgate, desdobramentos, agrupamentos, conversão e transferências de títulos negociados em pregão, o recebimento de margens para as garantias de operações realizadas por Sociedades Corretoras.

\section{CALISPA}

a Caixa de Liquidação da Bolsa de Valores de São Paulo.

\section{CÂMARA DE COMPENSAÇÃO}

instituição fundada por convênio de Bancos para a compensação de cheques, entre si, evitando assim movimentação de dinheiro em espécie.

\section{CAMBIAL}

letra de câmbio, letra sacada numa praça sobre outra; de câmbio, que se refere a câmbio.

\section{CÂMBIO}

operação de conversão de moedas ou obrigações de um país pelo equivalente de outro; relação de valores entre moedas de dois ou mais países.

\section{CÂMBIO LIVRE}

operação cambial regulada pela lei de oferta e procura. 


\section{CÂMBIO MANUAL}

a troca física de uma moeda por outra.

\section{CÂMBIO OFICIAL}

taxas de conversão entre moedas fixadas pelas autoridades monetárias, relacionadas à moeda em curso num país.

CÂMBIO PARALELO (negro)

operação cambial efetuada por pessoas ou estabelecimentos não autorizados a operar em câmbio; a taxa de conversão nesse mercado.

\section{CAPATAZIA}

quantia paga por volume de mercadoria embarcada.

\section{CAPITAL}

a quantia representada pelos recursos mobilizados numa empresa, para sua constituição e operação. $O$ dinheiro dos sócios de uma empresa, usualmente dividido em ações quotas ou participação. A empresa deve aos sócios até - valor do capital. O dinheiro ou valor monetário que constitui o fundo de uma empresa, ou o principal de uma renda.

\section{CAPITAL ABERTO (Sociedade)}

sociedade anônima especialmente registrada como tal, por tempo fixado em lei, cujas ações estão distribuídas por elevado número de acionistas.

\section{CAPITAL CIRCULANTE}

- numerário de uma empresa. Capital circulante, líquido:

a soma algébrica do Disponível, mais o Realizável a Curto Prazo menos o Exigível a Curto Prazo.

\section{CAPITAL FECHADO (Sociedade)}

a sociedade anônima que não preenche os requisitos para registro de capital aberto.

\section{CAPITAL FIXO}

capital empregado em bens imóveis, máquinas e equipamentos.

\section{CAPITAL DE GIRO}

v. Capital Circulante. 
CARENCIA

prazo concedido pelo financiador, durante o qual a amortização do principal é dispensada.

CARTEIRA

conjunto de títulos ou valores de que uma pessoa física ou jurídica dispõem.

\section{CARTEIRA DE CRÉDITO}

departamento de instituição financeira que regula a concessão de empréstimos a cliente.

\section{CARTEIRA DE TÍtULOS}

portfolio; conjunio de títulos e valores pertencentes a uma pessoa ou empresa; as carteiras podem ser concentradas ou diversificadas, isto é, podem conter pequena ou grande variedade de títulos diferentes.

\section{CARTEL}

forma alemã do sindicato. E o acordo entre empresas com o fito de monopolizar o mercado.

\section{CAUÇÃO}

Depósito em valores como garantia de cumprimento de contrato ou de liquidação de débitos. Depósitos de ações para garantia de mandato de diretor de S.A.; a caução pode ser prestada com bens de terceiros.

CAUtela

certificado de um título de propriedade (ação). Título que representa tantas ações de uma empresa quantas estiverem indicadas, com especificação de tipo, quantidade, caracterização do titular, alterações estatutárias que modifiquem as características do título, direitos acionários já exercidos pelas ações representadas na cautela.

\section{CÉdULA}

toda espécie de papel em que haja obrigação, seja passada pelo poder público, seja por particular.

\section{CÉDULA HIPOTECÁRIA}

título emitido sob garantia hipotecária ou sob o valor de hipoteca efetivada. 


\section{CÉDULA PIGNORATÍCIA}

título emitido para circulação de crédito decorrente de um penhor.

\section{CERTIFICADO}

atestado em que se certifica um fato; documento legal que certifica.

\section{CERTIFICADO DE PROPRIEDADE}

documento que certifica a propriedade de um valor ou bem;

\section{CERTIFICADO DE DESDOBRAMENTO}

documento emitido pelas Caixas de Liquidação, comprovando que as cautelas que representa encontram-se em fase de desdobramento;

\section{CERTIFICADO DE COMPRA DE AÇÕES}

documento emitido pelos fundos fiscais, para comprovar a aplicação de parcelas do imposto de renda devido, a título de incentivos fiscais;

\section{CERTIFICADO DE INVESTIMENTO}

a cautela de um fundo mútuo de investimentos, representando um número de quotas desse fundo;

\section{CERTIFICADO DE DEPÓSITO BANCÁRIO}

documento negociável, que representa um depósito a prazo fixo realizado em Bancos de Investimentos ou Banco Comercial.

\section{CHEQUE}

ordem de pagamento para a soma que determinar, por conta de fundos bancários de propriedade do emitente da ordem.

\section{CHEQUE AO PORTADOR}

sem identificação do beneficiário;

\section{CHEQUE NOMINAL}

com identificação do beneficiário;

\section{CHEQUE AVULSO}

cheque fornecido ao correntista de um Banco que não tem consigo seu talão usual; 


\section{CHEQUE MARCADO}

cheque em que o Banco designa, com a concordância do beneficiário, dia certo para pagamento, passando a ser o único responsável;

\section{CHEQUE CRUZADO}

só pode ser descontado por um Banco. É cruzado por duas linhas paralelas apostas pelo emitente.

\section{CHEQUE BANCÁRIO}

cheque emitido por um banco, não por um correntista.

\section{CHEQUE VISADO}

por meio de chancela especial, garante o pagamento da importância declarada;

\section{CHEQUE DE VIAGEM}

comprado ao Banco, em valores fixos, no qual o emitente apõe duas assinaturas; uma na hora da aquisição, outra quando transacioná-lo ou convertê-lo em moeda.

\section{CLUBE DE INVESTIMENTOS}

associação de investidores para reunir fundos com vistas a operar no mercado de ações; o clube é administrado pelos sócios, e supervisionado por sociedades corretoras membros das Bolsas de Valores; suas características básicas assemelham-se àquelas dos fundos mútuos de investimentos, mas sem obrigatoriedade de patrimônio mínimo.

\section{CNBV}

Comissão Nacional de Bolsa de Valores - instituição civil que congrega as Bolsas de Valores do País, com vistas principalmente à manutenção do Mercado Nacional de Valores Mobiliários.

\section{COFIE}

Comissão de Fusão e Incorporação de Empresas, criada pelo Governo Federal, vinculada ao Ministério da Fazenda. É instrumento de Incentivo à fusão de empresas, que visa estimular a formação dos aglomerados industriais, e abertura do capital das pequenas e médias empresas. 


\section{COHAB (Cooperativa Habitacional).}

organismo do Sistema Financeiro da Habitação, destinados à construção e financiamento da casa própria com características populares.

\section{COMPENSAÇÃO}

acerto de contas entre credores e devedores por apuração de diferenças.

\section{CONCORDATA}

acordo entre o devedor e os credores para pagamento parcial de dívida contraída, em virtude de estado de insolvência daquele.

\section{CONDOMINIO}

domínio conjunto de duas ou mais pessoas. Coisa indivisa, cuja propriedade está dividida entre duas ou mais pessoas. Patrimônio dos fundos de investimentos.

\section{CONDOMÍNIO ABERTO}

aquele em que se admite a entrada de novos donos de partes ideais do patrimônio.

\section{CONDOMÍNIO FECHADO}

aquele em que o número de condôminos é limitado pelo regulamento condominal.

\section{CONSELHO FISCAL}

órgão coletivo de uma sociedade anônima, composto de no mínimo três membros efetivos, não ligados à sociedade, cuja função é fiscalizar e opinar sobre a vida financeira da empresa.

\section{CONSELHO MONETÁRIO NACIONAL}

órgão da administração federal, responsável pela formulação da política da moeda e do crédito, objetivando o progresso econômico e social do País.

\section{CONSÓRCIO}

associação, união, comunhão de interesses. Consórcio de automóveis: associação de compradores de automóveis que fazem caixa comum para a aquisição desses bens; consórcio financeiro: união de instituições financeiras visando à concretização de uma operação de grande porte. 
CONTA

cálculo; cômputo; classe denominada de valores em que, contabilmente, se decompõe um patrimônio.

\section{CONTA CORRENTE}

contrato pelo qual duas pessoas convencionam que os diferentes débitos ou créditos resultantes das transações entre elas sejam lançados em uma conta assim denominada, compensando-se os respectivos débitos e créditos, até a liquidação por saldo nas épocas estabelecidas.

\section{CONTA BANCÁRIA}

a conta corrente em que uma das partes é um Banco; conta corrente em que uma das partes é representada por dois ou mais titulares, que dispõem solidariamente dos fundos da conta.

\section{CONTA DE LUCHOS E PERDAS}

demonsirração de receitas e despesas das empresas, que permite verificar, num determinado período financeiro, os lucros ou prejuízos e a forma de distribuição daqueles.

\section{CONTA DE RESULTADO}

as diversas rubricas contábeis da conta de lucros e perdas.

\section{CONTA VINCULADA}

conta bancária, cujo movimento está condicionado a operações com fins específicos.

\section{CONVERSÃO}

mudança nas características de um título (ação ou obrigação). Nas ações, mudança da condição de "nominativa", para "ao portador", e vice-versa. Nas debêntures conversíveis em ações, a alteração da situação de debênture (obrigação) para ação.

\section{CORREÇÃO MONETÁRIA}

nova atribuição de valor aquisitivo à moeda brasileira de acordo com índices oficiais. Os bens imobilizados das sociedades, o capital de giro, os débitos fiscais, e determinados títulos estão sujeitos à correção monetária. Todo o 
esquema financeiro duo BNH também está montado sobre o instituto da correção monetária.

CORREÇÃo PREFIXADA

o valor, fixado antecipadamente, atribuído a um título de crédito.

\title{
CORRENTISTA
}

depositante de dinheiro em Banco.

\section{CORRETAGEM}

a atividade do agente intermediário de papéis financeiros; - valor do pagamento pela atuação do corretor; nas operações em Bolsa de Valores, a tabela de corretagens é uma só, para todo o País.

\section{COTAÇÃO}

- preço certo e ajustado de uma ação ou obrigação, nos negócios efetuados em Bolsa ou no mercado de balcão, Variações na cotação determinam a alta ou a baixa do valor do mercado de um título. Indicação do preço corrente; divulgação desse preço.

\section{SIGLA DO QUADRO DE COTAÇÕES}

\author{
AB (PREÇO DE ABERTURA) \\ - preço do primeiro negócio realizado no dia.

\section{UP (ÚLTIMO PREÇO)} \\ o preço do último negócio.

\section{UQ (ÚLTIMA QUANTIDADE)}

a quantidade transacionada no último negócio.

\section{MA (MÉDIA ANTERIOR)}

- preço médio da ação nos negócios do dia anterior. MI/MA (MÍNIMO/MÁXIMO)

- preço mínimo e o preço máximo da ação no dia presente.

\section{QT (Quantidade Total)}

a soma de todos os negócios realizados. 


\section{CRÉdITO}

facilidade de ter dinheiro adiantado para a atividade econômica; denominação de empesas que operam no forncimento de adiantamento a outras empresas ou a pessoas; soma posta à disposição de alguém; parte de uma conta onde se escrituram as dívidas ativas.

\section{CRÉDITO PIGNORATÍCIO}

o crédito concedido mediante garantias de penhor de bens;

\section{CRÉDITO COMERCIAL}

crédito concedido mediante garantias comerciais (títulos de efeitos comerciais);

\section{CREDITO DIRETO AO CONSUMIDOR}

crédito concedido diretamente ao comprador de bens duráveis, para que este negocie com o comerciante, à vista;

\section{CRÉDITO A DESCOBERTO}

aquele dado sem garantia real, apoiado apenas na idoneidade de pessoa por ele beneficiada;

\section{CRÉDITO PRIVILEGIADO}

aquele que, por lei, tem preferência sobre outros, para efeitos de pagamento.

\section{CREDOR PIGNORATÍCIO}

- credor que tem seu crédito garantido por penhor. Tem

- privilégio sobre os bens dados em penhor.

\section{CREDOR QUIROGRAFÁRIO}

- credor que não possui qualquer título de garantia ou preferência em relação aos bens do devedor, devendo, por isso, ser pago segundo a força dos bens livres do devedor.

\section{CUPOM}

parte destacável de um título (patrimonial ou de crédito) para o exercício autônomo de um direito do titular. Cupons para recebimento de dividendos, bonificações, juros e/ou correção monetária, renda mensal, etc. Os títulos e valores mobiliários utilizam cupons ou carimbos para expressar que o direito do titular já foi exercido. 
D

DEALER

comerciante, no mercado de capitais, que mantém estoques de determinados títulos e geralmente se especializa em comprar e vender certas classes de títulos, dando cotações firmes e permanentes de compra e venda.

\section{DEBENTURE}

título de dívida, amorîizável, garantido normalmente pelos bens do ativo das empresas;

\section{DEBENTURES CONVERSIVEIS EM AÇÕES}

- mesmo título, possuidor de cláusula que permite a sua conversão em ações da empresa, na forma prevista no corpo do próprio título. Até a data da conversão, o portador de debêntures conversíveis goza dos direitos de renda atribuídos à debênture; a partir dessa data, goza dos direitos estatutários do tipo de ação em que a debênture se converteu.

\section{DECRETO-LE] 157}

instrumento federal de estímulo à capitalização das empresas e à formação de poupanças. Com base nele, as pessoas físicas contribuintes do imposto de renda podem abater $12 \%$ do imposto de renda, devido, para aplicação em certificados de compra de ações de fundos fiscais, administrados por instituições financeiras especialmente criadas para tal fim.

\section{DEFICIT}

diferença negativa entre a receita e a despesa.

\section{DEL-CREDERE}

comissão que o intermediário cobra em garantia, ao vendedor, da solvência do comprador.

\section{DELIBERAÇÃO}

resolução tomada por uma assembléia.

\section{DEPÓSITOS}

ato de depositar, confiar à guarda de alguém. 


\section{DEPÓSITO À VISTA}

depósito em dinheiro em conta corrente bancária, sacável à vista pelo depositante.

\section{DEPÓSITO DE AVISO PRÉVIO}

depósito em que o depositante faz saber ao Banco em que data retirará o valor depositado.

\section{DEPÓSITO A PRAZO FIXO}

depósito efetuado em Banco Comercial ou de investimentos, a prazo predeterminado, que não pode ser levantado antes do prazo decorrido. Rende juros e correção monetária prefixada.

\section{CERTIFICADO DE DEPÓSITO A PRAZO FIXO}

título nominativo, endossável e negociável com terceiros que não o Banco que acolhe o depósito.

\section{RECIBO DE DEPÓSITO A PRAZO FIXO}

recibo não negociável representando depósito a prazo fixo.

\section{DEPÓSITO EM CONTA DE POUPANÇA}

depósito efetuado em instituições financeiras do Sistema Financeiro da Habitação (ver cadernetas de poupança), com juros e correção monetária, livremente movimentável peio depositante.

\section{DEPÓSITO MERCANTIL}

redução que se faz no valor nominal de um título.

\section{DESÁGIO}

contrato pelo qual uma pessoa recebe bens móveis para guardar.

\section{DESAGIAR}

reduzir o valor nominal de um título, para que a diferença se apresente como renda.

\section{DESDOBRAMENTO}

ato de desdobrar, de dividir. O desdobramento de uma cautela de ações em outras, equivalentes à mesma quantidade de ações da cautela original. Certificado de desdo- 
bramento; documento provisório, emitido pelas Caixas de Liquidação das Bolsas de Valores, que indicam que a operação de desdobramento está em curso da empresa emitente do título.

\section{DINHEIRO À VISTA}

é a expressão que se usa para designar o pagamento que é feito, imediatamente, tão logo se realize a operação.

\section{DINHEIRO EM ESPÉCIE}

assim se diz do dinheiro metálico ou seja, aquele que se fabrica com metais preciosos (ouro e prata). Por extensão, aplica-se a locução para o papel moeda.

\section{DINHEIRO A RISCO}

empréstimo que uma pessoa faz a outra, mediante um prêmio certo, com garantia de cousas expostas a riscos marítimos, sujeitando-se a perder o capital e a renda, se houver um acidente.

\section{DIREITOS}

retribuição regulamentar, estatutária ou legal dada àquele que adquire um título ou valor; os rendimentos, e vantagens correspondentes ao título. Nos títulos de crédito, a renda é um direito inerente ao título.

\section{DIREITO DE SUBSCRIÇÃO}

direito reservado aos acionistas de subscrever novas ações da sociedade, quando de aumentos de capital sob essa forma, na proporção das ações já possuídas, ou em outras que os estatutos determinarem. $O$ direito de subscrição, normalmente, é transferível a terceiros, contra pagamento ou não. Os direitos devem ser exercidos na forma dos estatutos ou da lei, para se manterem.

\section{DISTRIBUIÇÃO}

\section{DISTRIBUIÇÃO DE DIVIDENDOS}

pagamento desse direito.

\section{DISTRIBUIÇÃO DE RENDA}

pagamento de renda. 


\section{DIVIDENDO}

parcela de lucro que deve ser distribuída entre os acionistas ou cotistas de uma sociedade. A distribuição se dá em moeda corrente. Existem incentivos fiscais que reduzem a tributação dos dividendos das sociedades anônimas de capital aberto, de 25 para 15\%. Os dividendos podem ser fixos ou atribuídos ao fim de cada exercício; podem ainda ser cumulativos, dependendo do que estabelecerem os estatutos da sociedade.

\section{DOMINIO}

qualidade de proprietário; propriedade; faculdade de dispor de um bem ou valor. Reserva de domínio: transferência da faculdade de dispor de um bem ou valor a terceiro, normalmente como garantia de dívida.

\section{DUMPING}

venda de um produto abaixo do preço de mercado vigorante no país ou região de origem, visando anular a concorrência.

\section{DUPLICATA}

título de crédito formal, nominativo, emitido por comerciante com a mesma data, valor global e vencimento da fatura, representativo e comprobatório de crédito pré-existente (venda de mercadorias a prazo), destinado a aceite e pagamento do comprador, circulável por meio de endosso e sujeito à disciplina do direito cambial. Também pode ser emitida duplicata à prestação de serviço.

\section{$\mathbf{E}$}

\section{EMBRAER}

sociedade de economia mista, em que o governo detém $51 \%$ do capital, ficando os demais $49 \%$ para serem subscritos por pessoas jurídicas ou físicas. Até o exercício financeiro de 1975, inclusive, as pessoas jurídicas poderão deduzir $1 \%$ do imposto de renda devido, a título de incentivo fiscal, para aquisição de ações novas da EMBRAER. 


\section{EMBRATUR (Empresa Brasileira de Turismo)}

entidade autárquica à qual compete planejar, executar e controlar a ação federal, visando ao incremento do turismo em todo o território nacional.

EMITENTE

pessoa que emite ou saca um título, criando uma obrigação de pagamento.

\section{EMPENHAR}

dar em garantia algum bem, título ou valor.

\section{EMPRESAS COLIGADAS}

empresas onde os sócios são comuns, em sua totalidade, ou em parte essencial.

\section{EMPRESA SUBSIDIÁRIA (Vinculada ou controlada)}

empresa cujo capital, em sua maior parte, pertence a outra empresa.

\section{EMPRESTIMO}

entrega de dinheiro a pessoa ou empresa para devolução em tempo prefixado, acrescido de taxas remuneratórias (juros e comissões).

\section{ENDOSSO}

assinatura do detentor de um título, usualmente colocada no verso deste último, repreentando a transferência do crédito para outrem.

\section{ESPECULAR}

negociar no mercado de capitais ou câmbio com o objetivo de auferir lucros, aproveitando-se de uma situação temporária do mesmo mercado. Operar na Bolsa jogando na alta ou na baixa dos títulos.

\section{EXTRATO DE CONTA}

sumário de uma conta qualquer, com indicação de saldo. 
$\mathbf{F}$

\section{FALÊNCIA}

ato ou efeito de falir; quebra. Execução coletiva da pessoa jurídica devedora, à qual concorrem todos os credores, visando a levantar o patrimônio disponível, verificar os créditos, solver o passivo e liquidar o ativo, mediante rateio, com observância das preferências legais.

\section{FATURA FISCAL (ou Noła Fiscal)}

documento que legitima a circulação da mercadoria, servindo também de base para a cobrança de imposto.

\section{FATURA SIMPLES (ou Conta de Venda)}

relação que acompanha a remessa de mercadorias expedidas, ou se remete mensalmente ao comprador, com a designação de quantidades, marcas, pesos, preços e importâncias, podendo estas referências ser substituídas por simples menção dos números e valores e notas fiscais ex. traídas e guardadas segundo determinação da lei.

\section{FAVORECIDO}

beneficiário; pessoa ou entidade em cujo nome se encontra o título ou direito. Aquele a quem se destina o pagamento da obrigação; credor.

FIADOR

aquele que presta fiança. Aquele que abona alguém, responsabilizando-se pelo cumprimento de obrigações do abonado.

FIANÇA

obrigação assumida por terceiros, responsabilizando-se total ou parcialmente pelo cumprimento da obrigação do devedor, quando este não a cumpre ou não a possa cumprir.

FIDUCIAL

que diz respeito a confiança.

(v. Moeda Fiduciária).

\section{FILHOTE}

(v. Bonificação) 
FINAME

agência especial de financiamento destinada à aquisição de máquinas e equipamentos industriais. O crédito, é fornecido quer ao comprador, quer ao fabricante, pelo BNDE isoladamente ou em regime de coobrigação com outros agentes financeiros.

\section{FINANCEIRAS}

sociedades de crédito, financiamento e investimento que se dedicam, principalmente, a operações de financiamento ao consumidor final de bens duráveis, através do sistema de aceite cambial.

\section{FINANCIAMENTO}

empréstimo de recursos levantados quer pela emissão de títulos ou valores mobiliários negociados com o público em geral, quer com recursos próprios de financiador.

Concessão de prazo para pagamento de dívidas comerciais. Empréstimo de dinheiro.

\section{FUNDAMENTALISTA}

orientação pela qual os investidores projetam possibilidades futuras de determinados papéis, através do exame da contabilidade das empresas e seu ramo de atividades, definindo a situação econômica e financeira das mesmas.

FUNDO

o conjunto de disponibilidades criado para desenvolver ou consolidar, através de financiamentos, um setor deficitário da atividade pública ou privada. Conjunto de recursos.

\section{FUNDOS DE INCENTIVOS FISCAIS (Decreto-Lei 157)}

fundos especiais criados pelo Decreto-Lei 157 para acorrer às deficiências de capital de giro e de capital fixo para as empresas, levando ao mercado de capitais um número crescente de novos investidores. As quotas destes fundos são adquiridas com a dedução de parcelas do imposto de renda a pagar pelos contribuintes. (v. Decreto-Lei 157).

\section{FUNDO MÚTUO DE INVESTIMENTOS (ou Fundo em Condomínio aberto)}

conjunto de recursos administrados por uma sociedade corretora, financeira ou banco de investimento (com exi- 
gências mínimas de capital) que os aplica em carteira de títulos ou valores mobiliários, distribuindo depois aos quotistas, proporcionalmente, os resultados de tais aplicações. Os participantes dos fundos mútuos adquirem quotas-partes ideais do valor das ações e títulos que compõem o condomínio.

\section{FUNDO DE RESERVA LEGAL}

fundo destinado a garantir a integridade do capital de uma sociedade anônima.

\section{FUSÃO DE EMPRESAS}

união de uma ou mais empresas de um mesmo ramo de atividade econômica.

\section{GARANTIA}

meio pelo qual o credor se precavém contra o devedor, de qualquer risco que a transação possa acarretar.

\section{GERES}

entidade do Governo do Estado do Espírito Santo, destinada a administrar e distribuir recursos de incentivos fiscais especialmente regulados para aquele Estado.

\section{GRÁFICO PONTO-FIGURA}

sistema de aferição e análise de tendências dos preços de uma ação, em função do seu comportamento no mercado.

\section{GRAFISTA}

orientação pela qual os investidores acompanham o mercado de valores através da análise de gráficos especiais, como o gráfico ponto-figura.

\section{H}

\section{HIPOTECA}

garantia de pagamento de dívida dada a um credor, representada por um bem imóvel, sem transferência da posse do bem em questão ao credor.

sociedade acionista ou sócia de outras. Sociedade em cadeia. Empresa que detém o controle acionário de outras empresas. 


\section{I}

IBDF - Instituto Brasileiro de Desenvolvimento Florestal

autarquia vinculada ao Ministério da Agricultura, encarre gado de desenvolver planos de florestamento no País, administrar e executar políticas de reflorestamento. O reflorestamento admite a dedução de até $50 \%$ do imposto de renda devido pelas pessoas jurídicas, e o abatimento pelas pessoas físicas, das despesas de reflorestamento incorridas, até o limite de $50 \%$ da renda bruta.

IBOVESPA (Índice da Bolsa de Valores de São Paulo)

IMPOSTO DE RENDA

imposto federal que incide sobre os lucros auferidos pelas empresas, e sobre os rendimentos das pessoas físicas.

\section{IMPOSTO RETIDO NA FONTE}

imposto cobrado no momento da percepção de certos rendimentos, através da própria fonte pagadora. No caso do imposto de renda de pessoa física, tal recolhimento antecipado é dedutível do imposto a pagar no exercício seguin. te.

\section{INBV (Índice Nacional das Bolsas de Valores)}

representativo da evolução das cotações do mercado nacional. (v. Mercado Nacional).

\section{INCENTIVOS FISCAIS}

instrumento de política fiscal destinado pela renúncia de parte de receita federal tributária, a fomentar a atividade econômica e promover o desenvolvimento de certas regiốes econômicas ou de certos setores da atividade pública ou privada. Traduzem-se pela faculdade dada ao contribuinte de deduzir do imposto de que sejam devedores, as quantias investidas naquelas regiões ou setores. $O$ setor público transfere, então, para a iniciativa privada a responsabilidade da execução de projetos de investimento definidos segundo os objetivos políticos do Poder Público.

\section{INCORPORAÇÃO DE EMPRESAS}

compra de uma ou mais empresas por uma empresa maior. 


\section{INCORPORAÇÃO DE RESERVAS}

operação contábil pela qual os lucros não distribuídos em exercícios anteriores, assim como outras reservas livres, são levados à conta de capital.

\section{INCORPORADOR}

fundador de uma sociedade anônima.

\section{INDENIZAÇÃO}

repação; compensação; reembolso.

ÍNDICE

valor numérico abstrato que retrata a oscilação do mercado mobiliário, com base na média das cotações de um grupo de ações que o representa, referido a uma data determinada.

\section{INFLAÇÃO}

aumento dos níveis de preços. Emissão excessiva de papel. moeda, provocando a redução do valor real de uma moeda em relação a determinado padrão monetário estável ou ao ouro.

\section{INSOLVÊNCIA}

situação na qual o devedor não pode pagar o que deve.

\section{INTEGRALIZAÇÃO}

o ato de concluir o pagamento de um título que se adquiriu. Normalmente usado nas subscrições de ações ou debêntures conversíveis, em que o pagamento se faça por etapas.

\section{INTEGRALIZAÇÃO NO ATO}

o pagamento integral de uma só vez.

\section{INVENTÁRIO}

balanço; levantamento completo dos bens e valores ativos e passivos de uma sociedade ou pessoa.

\section{INVESTIDOR}

a pessoa ou empresa que aplica suas poupanças ou disponibilidades na aquisição de ações ou títulos comercializados no mercado financeiro. 


\section{INVESTIMENTO}

aplicação de capital em determinado negócio, empresa, ou projeto ( $v$. investidor). Usa-se também, mais propriamente, a palavra inversão como sinônimo de investimento.

\section{ISENÇÃO FISCALL}

dispensa legal do pagamento de um tributo devido.

\section{J}

JURO

taxa percentual incidente sobre um valor ou quantia, numa unidade de tempo determinada.

\section{JUROS DE MORA}

os que o devedor paga, sobre o devido, da data do vencimento até o dia em que faz o pagamento.

\section{$\mathbf{L}$}

\section{LANÇAMENTO}

colocação de títulos novos no mercado de capitais, por conta própria ou através de intermediários financeiros.

\section{LANCE}

oferta de compra ou venda de ações.

\section{LEASING}

operações de arrendamento de equipamentos industriais, com opção de comprar pelo arrendatário no término do contrato.

\section{LETRA BANCÁRIA}

é a sacada por um banco sobre a matriz, filial, agência, escritório, correspondente ou sobre si mesmo.

\section{LETRA DE CÂMARA}

bilhete ou letra emitida por prefeitura ou municipalidade. 


\section{LETRA DE CÂMBIO}

ordem de pagamento com valor, vencimento e praça de pagamento explícitos. É emitida por pessoas físicas ou jurídicas (sacadoras), aceita por instituições financeiras (sociedades financeiras ou Bancos de Investimento) e colocada junto ao público investidor. $O$ aceite cambial evidencia que aquele que aceitou é o primeiro obrigado a honrar o resgate da letra, porque afirmou a existência de fundos para honrar o resgate na data prevista.

\section{LETRA HIPOTECÁRIA}

título emitido por um banco de crédito real, mediante garantia de um imóvel; mutuário é o portador de letra dessa espécie.

\section{LETRA IMOBILIÁRIA}

título de promessa de pagamento emitido pelo Banco Nacional de Habitação ou por sociedade de crédito imobiliário. O capital levantado com a venda dessas letras destina-se carrear recursos para o Sistema Financeiro da Habitação, cuja missão é o financiamento de moradias de porte médio. As emissões das letras imobiliárias são autorizadas e controladas pelo próprio $\mathrm{BNH}$, vencendo juros e correção monetária e podendo ser nominativas ou ao portador.

\section{LETRA A PREMMIO}

título que o Banco dá ao depositante de dinheiro a prazo fixo.

\section{LETRA DO TESOURO NACIONAL}

título emitido pelo governo federal, para operações de "open market", negociadas com deságio.

(v. "open market").

\section{LIMITE}

de alta ou de baixa, valor estipulado diariamente pelas Bolsas de Valores, como limites de preço para negociação de uma ação. Não se poderá vender abaixo do limite de baixa, nem comprar acima do limite de alta. No dia do lançamento na sala de pregão, ou conforme a decisão de uma Bolsa, ações poderão ser negociadas "sem limite de preço". 


\section{MQUIDAÇÃO}

ato de liquidar; apuramento de contas; operação pela qual uma casa comercial paga o passivo e distribui o ativo pelos sócios.

LQQUIDEZ

grau de negociabilidade de um título, sua possibilidade de ser transformado em dinheiro a qualquer momento.

\section{LIQUIDEZ BANCÁRIA}

disponibilidade do sistema bancário em caixa ou ou realizável a curto prazo.

\section{ÍNDICE DE LIQUIDEZ}

relação entre as disponibilidades e exigibilidades de uma sociedade.

\section{LOTE}

conjunto de cautelas, certificados ou títulos de qualquer natureza. Lote redondo: lotes de 100 e 1.000 ações.

\section{M}

\section{MARGEM}

nas operações o termo, em Bolsa de Valores, a parte do valor da operação que o comprador e o vendedor a termo depositam como garantia contra eventuais não-liquidações da operação contratada. A margem, pelo comprador, pode ser depositada em dinheiro e em títulos.

MERCADO

área em que os compradores e vendedores estabelecem contato e realizam transações; instituição de transações de compra e venda de forma contínua.

\section{MERCADO DE BALCÃO}

compra e venda de títulos fora das Bolsas de Valores.

\section{MERCADO DE CAPITAIS}

procura e oferta de recursos financeiros disponíveis como poupança para aplicação em investimentos. 


\section{MERCADO ESTREITO}

mercado de uma ação ou título com baixo volume de transações médio diário.

\section{MERCADO FINANCEIRO}

procura e oferta de dinheiro.

\section{MERCADO FIRME}

fase do mercado de ações em que as cotações dos papéis negociados apresentam oscilações mínimas, em preço e volume de transações.

\section{MERCADO FRACIONÁRIO}

em Bolsa, conjunto das negociações com lotes fracionários de cem ou mil ações.

\section{MERCADO IMOBILIÁRIO}

mercado de bens imóveis.

\section{MERCADO LARGO}

mercado de uma ação ou título com alto volume de transações médio diário.

\section{MERCADO MOBILIÁRIO}

mercado de valores mobiliários.

\section{MERCADO NACIONAL}

convênio estabelecido por Bolsas de Valores brasileiros, visando ao registro único de empresas cotadas, funcionando a Bolsa onde se fez o registro como reguladora; as transações efetuadas com esses títulos.

\section{MERCADO PARALELO}

mercado cujas operações não são regulamentadas ou fiscalizadas.

\section{MERCADO PRIMÁRIO}

mercado de títulos em fase de lançamento para subscrição pública. Pode ser desenvolvido fora da Bolsa.

\section{MERCADO SECUNDÁRIO}

mercado de títulos já lançados, obrigatoriamente em Bolsas, onde as houver, se se tratar de sociedades de capital aberto. 


\section{MERCADO A TERMO}

mercado de ações ou títulos onde as operações de compra ou venda são liquidadas em prazo determinado posterior à sua realização, acima de 5 dias.

\section{MERCADO À VISTA}

mercado de ações ou títulos onde as operações de compra ou venda são liquidadas quando de sua realização.

\section{MOEDA CORRENTE}

moeda de curso legal em um país.

\section{MOEDA FIDUCIÁRIA}

papel-moeda - e bilhetes ou notas de banco (cheques).

MONOPÓHO

privilégio que uma pessoa, sociedade ou governo tem para vender sem concorrentes certas mercadorias ou explorar determinada indústria.

MORA

atraso no pagamento de um título de crédito.

MORATÓRIA

prorrogação concedida ao devedor para o prazo de pagamento.

\section{MUTUANTE}

cedente de um empréstimo.

\section{MUTUÁRIO}

tomador de um empréstimo.

\section{$\mathbf{N}$}

\section{NEGÓCIO DIRETO}

transação realizada em Bolsa, onde uma mesma Sociedade Corretora é intermediária na compra e na venda de um mesmo lote. Os negócios "diretos" são apregoados nos postos de negociação, sendo lícita a interferência de outras corretoras, comprando a preço maior, ou vendendo a preço menor. 


\section{NOTA PROMISSÓRIA}

título de crédito que representa a promessa de pagamento, pelo emitente, de determinada importância ao beneficiário, em lugar e tempo prefixados.

\section{NOTA PROMISSÓRIA RURAL}

título de promessa de pagamento originado de transações agrícolas ou pastoris e emitido diretamente pelos produtores ou pelos proprietários rurais.

\section{NOVAÇÃO}

conversão de uma obrigação em outra, extinguindo-se a primeira.

\section{NUMERÁRIO EFETIVO}

dinheiro em caixa.

\section{OBRIGAÇÕES REAJUSTÁVEIS DO TESOURO NACIONAL}

títulos emitidos pelo governo federal que vencem juros e cujos valores de emissão são periodicamente acrescidos de correção monetária fixadas pelas autoridades.

\section{OPEN MARKET}

operações de mercado aberto, realizadas pelo Banco Central, no sentido de regular o fluxo de dinheiro oferecido no mercado monetário. Quando há muito dinheiro em circulação o BC vende suas Letras do Tesouro Nacional, recolhendo dinheiro do mercado. No caso inverso, ele injeta dinheiro no mercado comprando suas letras.

\section{OPERAÇÃo A TERMO}

compra e venda de títulos para liquidação em prazo superior a cinco dias, a contar de sua realização.

\section{OPERAÇÃo À VISTA}

operação de compra e venda de títulos para liquidação dentro de quarenta e oito horas, após ter sido fechada no pregão. 


\section{OPERADOR}

funcionário de uma Sociedade Corretora, credenciado nas Bolsas de Valores, e encarregado de apregoar ofertas para compra ou venda de títulos, e fazer o fechamento das operações.

\section{ORÇAMENTO}

previsão da receita e da despesa.

\section{ORÇAMENTO PÚBLICO}

previsão da receita a ser arrecadada em um exercício financeiro e das despesas a ser feitas pela administração pública (federal, estadual, municipal), organizado obrigatoriamente pelo Executivo e submetido à aprovação das respectivas câmaras legislativas. ,

\section{ORDEM FIRME}

ordem em que se estipulam preços e condições para a concretização da transação; ordem "ao mercado", ordem em que se autoriza o negócio, aos preços correntes no mercado do dia. A "ordem ao mercado" deve ser cumprida no dia especificado, desde que haja mercado para o título.

\section{ORDEM DE OPERAÇÕES}

ordem dada pelo investidor ao seu corretor, para a realização de uma operação de mercado (compra, venda, etc.).

\section{ORDEM DE PAGAMENTO}

instrumento pelo qual alguém autoriza outrem (geralmente um banco) a pagar certa quantia a um terceiro.

\section{OSCILAÇÃo DE TÍTULO}

movimenio alternativo de alta ou baixa que os títulos sofrem em seus valores.

\section{$\mathbf{P}$}

\section{PAINEL}

quadro onde se registram as operações relativas às ações das empresas, durante o pregão nas Bolsas de Valores. 


\section{PAPEL}

qualquer valor mobiliário de transação corrente.

\section{PAPEL COMERCIAL}

documento, título de crédito ou contrato emitido em decorrência de uma obrigação assumida em transação comercial.

\section{PAPEL FRIO}

ação sem possibilidades de venda ou rendimento no mercado. Título sem valor.

\section{PAPEL QUENTE}

ação com possibilidades de venda ou rendimento no mercado. Título com valor de mercado.

\section{PAR}

valor idêntico ao oficial ou nominal, pago na compra de títulos, moedas ou obrigações.

\section{PARTES BENEFICIÁRIAS}

títulos negociáveis, não integrantes do capital, sem valor nominal, emitidos a qualquer tempo pelas sociedades anônimas e que conferem aos proprietários participação de até $10 \%$ nos lucros.

\section{PARTES DE FUNDADOR}

partes beneficiárias que podem ser instituídas na fundação da sociedade anônima para distribuição aos fundadores da empresa.

\section{PARTICIPAÇÃO}

o ato ou a forma de participar. Os direitos de participação nos resultados, no caso das ações preferenciais. De acordo com os estatutos de uma empresa, as ações preferenciais podem ser limitações na participação integral nos resultados. É comum, em empresas formadas ao abrigo da política de incentivos fiscais, estabelecerem-se restrições na distribuição dos lucros, para ações preferenciais de determinados tipos, ou "classes".

\section{PASSE}

licença; bilhete de trânsito; remessa de dinheiro de uma praça a outra por intermédio de banco (giro bancário). 


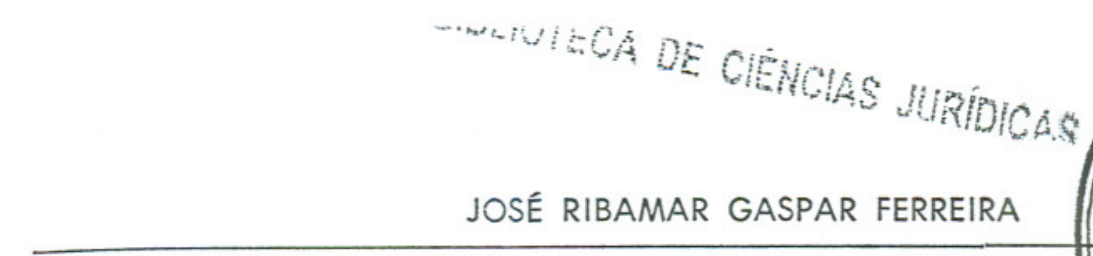

PASSIVO

PATRIMONNIO

a totalidade dos débitos de uma empresa du pessoa.

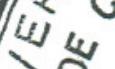

a expressão, em dinheiro, do valor líquido do total dos bens e obrigações de uma pessoa ou empresa.

\section{PATRIMONNIO LÍQUIDO}

diferença entre o ativo e o passivo de uma empresa, quando o primeiro é maior que o segundo.

PECÚLIO

a soma de poupanças acumuladas por uma pessoa, como resultado de seu trabalho.

PENHOR

garantia representada pela entrega de coisa móvel para assegurar o cumprimento da obrigação assumida.

\section{PESSOA FÍSICA}

a própria pessoa natural. O indivíduo considerado como contribuinte fiscal.

\section{PESSOA JURÍDICA}

entidade de direito público (União, Estado, Município) ou privado (sociedade civil, mercantil, associação, fundação).

PONTE

diz-se do intermediáro (corretor) que liga o comprador com o vendedor.

PONTO

unidade usada para expressar a variação dos índices ou médias.

POOL

reunião ou combinação temporária entre empresas visando fins especulativos. Consórcio.

\section{PORTFOLIO}

v. Carteira de Títulos.

POSTO

local das Bolsas de Valores onde se processam as operações de compra e venda de títulos. 
POUPANÇA

diferença entre a renda e o consumo de pessoa física ou jurídica passível de ser transformada em investimento.

PRAZO

tempo concedido ao devedor para liquidar a conta; pode ser:

a) a dia certo, quando se precisa a data.

b) de data, quando contado do dia lançado pelo credor;

c) de vista, quando contado do dia do aceite.

PRAZO FIXO

(v. Depósito a prazo fixo).

\section{PRAZO DE SUBSCRIÇÃO}

prazo para subscrição preferencial de ações pelos já acionistas, em sociedades anônimas.

\section{PREÇO/LUCRO}

índice que mede o prazo para retorno do capital investido em uma ação. Obtém-se dividindo a cotação de Bolsa pelo lucro anual por ação, tirado da análise de balanços da empresa. O inverso do índice preço/lucro chama-se "taxa de retorno de capital", e mede em percentagem, quanto do capital aplicado em uma ação retorna anualmente ao investidor.

\section{PREGÃO}

declaração, pelo corretor, das condições em que vende ou compra certos títulos. Local onde se desenvolvem as negociações das Bolsas.

\section{PREMIO}

ágio exigido pelos subscritores de ações, de sociedade anônima. Diferença entre a taxa de emissão de debêntures e o preço do reembolso. Pagamento de uma determinada quantia quando, na liquidação de uma operação no mercado a termo, uma das partes não honrar o compromisso assumido.

\section{PRO-LABORE}

gratificação por serviço; há duas espécies: 


\section{PRO-LABORE FACIENDO}

por serviço que se faz;

PRO-LABORE FACTO

por serviço já prestado.

\section{PRO RATA TEMPORIS}

proporcional ao tempo decorrido.

\section{QUITAÇÃO (oU recibo)}

declaração expressa do credor de que recebeu parte ou a totalidade de determinado débito.

\section{QUOTA}

fração do capital de uma sociedade por quotas de responsabilidade limitada. Fração de um condomínio ou fundo de investimento.

\section{QUORUM}

número mínimo, exigido por lei, para que, legalmente, possa funcionar uma assembléia geral da sociedade.

\section{$\mathbf{R}$}

\section{RATIO}

razão; relação numérica entre contas que se extrai para observação dos aspectos de uma situação ou marcha de um negócio.

\section{REAPLICAÇÃO}

ajuste pelo qual o investidor autoriza sejam os seus rendimentos utilizados em novas aplicações.

\section{RECEITA}

complexo dos recursos monetários com que as pessoas jurídicas contam para cobrir as despesas de um exercício financeiro. 


\section{RECIBO DE TÍTULO}

documento provisório, comprobatório da posse de um título. Em certos casos, o recibo é negociável, podendo ser contado no pregão das Bolsas de Valores.

\section{REDESCONTO}

operação pela qual uma instituição financeira desconta em outra títulos, que, por sua vez, descontou para terceiros.

RÉDITO

lucro, juro, rendimento.

\section{REEMBOLSO}

indenização; restituição do que se emprestou.

\section{REFORMA (de título)}

prorrogação do vencimento pelo valor total ou parcial

\section{RENDA FIXA}

renda que vem prescrita no corpo do título ou valor mobiliário; os títulos de crédito, certificados de depósito e os títulos da dívida pública tem renda fixa. A renda fixa pode ser prefixada, ou vinculada à correção monetária.

\section{RENDA VARIÁVEL}

renda que não é pré-contratada, nem faz parte das condições do título emitido. As ações das sociedades anônimas, as quotas de fundos mútuos e fiscais têm renda variável Renda que depende das condições de mercado.

\section{RENDIMENTO}

provento de dinheiro, bens ou serviços que uma pessoa ou empresa aufere de suas atividades profissionais ou de transações mercantis ou civis. Renda.

\section{RENTABILIDADE}

caráter ou qualidade do que produz renda. Taxa ou nível de rendimento de uma aplicação ou investimento.

\section{RESERVAS}

partes dos lucros, obtidos por uma empresa, retidos para garantir a integridade do capital ou atender a outros fins. 


\section{RESERVA DE DOMÍNIO}

manutenção pelo vendedor da propriedade de determinado bem vendido a prazo. Enquanto a dívida não é inteiramente saldada, o comprador detém apenas a posse do bem.

\section{RESGATE}

pagamento de título.

\section{S}

SACADO

pessoa ou entidade ou responsável pelo pagamento de um cheque ou duplicata.

SACADOR

pessoa ou entidade que emite cheque, duplicata, ou letra de câmbio.

SALDO MEDIO

valor médio do saldo bancário de um correntista, usado como base para a concessão de empréstimos ou para operações de desconto.

\section{SEGURANÇA}

garantia de retorno do capital investido.

\section{SEGURO}

contrato pelo qual uma das partes se obriga em favor da outra, mediante pagamento de uma taxa (prêmio), à cobertura dos riscos relacionados no instrumento (apólice).

\section{SOCIEDADE ANÔNIMA}

sociedade em que o capital é representado por ações onde a responsabilidade do acionista se limita ao capital investido.

\section{SOCIEDADE DE CAPITAL AUTORIZADO}

companhias constituídas de capital inferior ao autorizado pelo estatuto social. As ações de suas emissões, só podem ser nominativas ou endossáveis. 


\section{SOCIEDADE CIVIL}

empresa sem objetivos comerciais. Na forma, pode seguir - modelo de qualquer sociedade comercial, menos o da sociedade anônima.

\section{SOCIEDADE CORRETORA}

instituições financeiras dedicadas a operar no mercado de capitais com títulos e valores mobiliários. As Corretoras compram, vendem e administram valores, transando nos mercados de balcão ("over-the-counter-market").

São os membros da Bolsa de Valores.

\section{SOCIEDADE DE CRÉDITO IMOBILIÁRIO}

sociedade de financiamento do Sistema Nacional da Habitação, através da colocação junto ao público das letras imobiliárias.

\section{SOCIEDADE DE CRÉDITO, FINANCIAMENTO E INVESTIMENTOS}

sociedade financeira que opera com o financiamento de bens de consumo durável, através do sistema de crédito direto ao consumidor final (v. Financeira).

\section{SOCIEDADE DISTRIBUIDORA}

empresas integrantes do sistema financeiro nacional que realizam o trabalho de revenda e distribuição de títulos e valores. Estas sociedades tem a missão específica de operar o mercado primário de ações (mercado de lançamento de papéis novos) ou da colocação de títulos não cotados nas Bolsas de Valores.

\section{SOCIEDADE LIMITADA}

sociedade comercial cujo capital se compõe de cotas e cuja responsabilidade dos sócios é limitada à importância total do capital, enquanto não integralizado.

\section{SUBSCRIÇÃO}

ato pelo qual uma pessoa ou empresa se obriga a pagar - preço das ações de aumento de capital que se comprometeu em adquirir. (v. direitos).

\section{SUCURSAL}

estabelecimento dependente de outro, em geral da matriz. 
SUDAM (Superinłendência de Desenvolvimento da Amazônia)

entidade autárquica à qual compete planejar, executar e controlar a ação federal na região amazônica, visando ao seu incremento e à sua valorização econômica.

SUDENE (Superintendência do Desenvolvimento do Nordeste)

entidade autárquica à qual compete planejar, executar e controlar a ação federal do Nordeste, com vistas a uma ampla reformulação do sistema vital dessa região do País e a valorização do homem nordestino.

\section{SUDEPE (Superintendência do Desenvolvimento da Pesca)}

entidade autárquica à qual compete planejar, executar e controlar a ação federal visando à implantação e ao desenvolvimento da indústria pesqueira.

\section{SUPERAVIT}

diferença positiva entre a receita e a despesa.

SWAP

a compra de câmbio pronta contra a venda de câmbio futura.

TARIFA

relação das taxas correspondentes a cada classe de risco (seguros); pauta de direitos alfandegários, tabela de preços.

TAXA

valor fixo ou percentual, que incide sobre um título ou negócio. Taxas de juros: valor percentual dos juros devidos ou havidos.

\section{TAXAS DE BOLSA}

as taxas de corretagem são reduzidas e de entendimento. Numa operação de compra e venda, até a importância de $\mathrm{Cr} \$ 5.000,00$, a corretagem cobrada é de 1,5\%. Se for superior a essa quantia e até $\mathrm{Cr} \$ 30.000,00$, a corretagem 'cai para $1 \%$. E se a operação envolver quantia superior a 30 mil a taxa é de $0,5 \%$. Preste muita atenção 
para o que se segue: esses percentuais são cumulativos. Se o investidor realizou uma operação de $\mathrm{Cr} \$ 8 \mathrm{mil}$ (serve para compra e venda), ele irá pagar a seguinte taxa de corretagem:

\begin{tabular}{|c|c|c|c|}
\hline $1,5 \%$ & até & $\mathrm{Cr} \$ 5.000,00$ & $=$ \\
\hline $1,0 \%$ & sobre & $\mathrm{Cr} \$ 3.000,00$ & $=$ \\
\hline
\end{tabular}

\section{TENDÊNCIA}

previsão do comportamento futuro das cotações de uma ação ou evolução de um índice.

TERMO

"fazer um termo": operar como comprador ou vendedor, no mercado a termo.

\section{TERMO DE POSSE}

documento que confirma a posse;

TERMO DE TRANSFERÊNCIA

documento que confirma a transferência de posse.

TIED LOAN

empréstimo obrigando o devedor a adquirir no país financiador os materiais ou produtos de que necessita para a execução de um projeto de investimento e na aquisição dos quais será aplicado o empréstimo. Ajuda vinculada.

\section{TÍTULO DE CRÉDITO}

documento formal, autônomo e negociável, representando obrigação de pagamento.

\section{TÍTULO DA DÍVIDA PÚBLICA}

papel de crédito emitido e garantido pela União, por um Estado ou por um Município, destinado a financiar o deficit governamental ou antecipar outras receitas públicas ou, ainda, servir de instrumento de política monetária, garantindo fluxo estável de meios monetários, no mercado de dinheiro. Tem características variáveis conforme a emissão, oferecendo renda prefixada ou renda real mais a correção monetária do capital investido. Normalmente traz indicado o prazo de resgate e a taxa de juros incidente. 


\section{TÍTULO DE FAVOR}

É o resultante de ajuste entre comerciantes, figurando nele, ficticiamente, devedor, credor e avalista. Sinônimos: título de circulação cruzada; "papagaio".

\section{TÍTULO AO PORTADOR}

título emitido sem a identificação do beneficiário.

TOMADOR

beneficiário original de cheque ou letra de câmbio; mutuáro.

\section{TRUST COMPANY}

companhia de administração.

\section{"UNDERWRITING"}

contrato celebrado entre uma empresa e uma instituição financeira, ou consórcio de instituições financeiras), para o lançamento público de suas ações ou debêntures. Os contratos de "underwriting" podem ser celebrados de três formas:

1. "straight": os lançadores da ação subscrevem a totalidade do lançamento, pagando-o diretamente à empresa.

2. "stand-by" - os lançadores colocam a emissão de ações junto ao público investidor, comprometendo-se a adquirir o saldo não vendido da emissão.

3. "best-efforts" - os lançadores comprometem-se a envidar esforços para a colocação da emissão de ações, devolvendo à empresa o saldo não colocado, eximindo-se da obrigação de subscrevê-lo.

\section{UPC (Unidade Padrão de Capital)}

forma pela qual entidades vinculadas ao Sistema Financeiro da Habitação atualizam o valor monetário do cruzeiro. Uma UPC equivale a uma Obrigação Reajustável do Tesouro Nacional. Valor pelo qual são emitidas as letras imobiliárias "De Poupança". 
USURA

ganho ilícito por parte do credor, a título de juros de quantias acima dos limites estabelecidos em lei.

\section{V}

VALE

documento representativo de dinheiro tomado emprestado.

VALOR NOMINAL

valor inscrito em cada ação ou cota em que se divide o capital de uma sociedade. Valor de emissão ou de resgate inscrito no título.

\section{VALOR REAL}

é o que efetivamente tem o título, deduzido o imposto sobre a renda, ou feito o deságio sobre o valor nominal.

\section{VALOR DE RESGATE}

soma paga por título de renda no dia do seu vencimento.

\section{VALOR VENAL}

valor real de transação. Valor de mercado.

\section{VALORES MOBILIÁRIOS}

documentos que representam as partes alíquotas de um capital ou de um crédito.

\section{VALORIZAÇÃO}

termo que indica a capitalização de um título em Bolsa. Diferença positiva entre o valor do título no mercado e o seu valor nominal. A medida de valorização das ações nas Bolsas é dada pelos ÍNDICES. Em São Paulo, o índice BOVESPA mede as valorizações de suas ações. No Rio, o índice é o IBV. Os índices são compostos das ações mais negociadas, de maior liquidez, portanto.

\section{VENCIMENTO}

data limite do prazo de pagamento de uma dívida. O dia do resgate do título. 


\section{VOTO (Direiło de)}

o direito que tem o proprietário de ações ordinárias (ou preferenciais não destituídas desta faculdade) de notar sobre os assuntos deliberados em assembléias, de acionistas. Cada ação equivale a um voto.

\section{W}

\section{WARRANT}

título representativo de mercadoria depositada em armazém geral e com que se pode dá-la em garantia de empréstimo, mediante endosso.

\section{$\mathbf{Z}$}

\section{ZANGÃO}

pessoa que, sem estar devidamente qualificando e registrado, opera nos mercados. 